\title{
Conceptual Design for an Anti-Thief Donation Box
}

\author{
Febrian Idral ${ }^{1,}$, Ahmad Fuad Ab Ghani ${ }^{1}$, Nur Amanina Syazwani ${ }^{2}$, Tan Chee Teck ${ }^{2}$, Nur Aliyah Abd Mutalib ${ }^{2}$, Mohd \\ Aiman Mohd Fadhil ${ }^{2}$, Muhamad Dzulhisham Idris ${ }^{2}$ \\ ${ }^{1}$ Centre for Advance Research on Energy, Universiti Teknikal Malaysia Melaka, Hang Tuah Jaya, 76100, Durian Tunggal, Melaka, \\ Malaysia \\ ${ }^{2}$ Faculty of Mechanical Engineering. Universiti Teknikal Malaysia Melaka., Hang Tuah Jaya, 76100, Durian Tunggal, Melaka, Malaysia
}

\begin{abstract}
The donation box is commonly used to collect money to from the society for charity purpose. Due to the increase case of the stealing involving donation box, it indicates that the current design of the box is not safe. A research survey are being conducted and the newly design Anti-Thief Donation Box is is introduced in this paper. The material chosen for prototype is mild steel upon its strength and durability. The manufacturing method involved are welding, grinding and drilling. Special specification on this donation box includes the dual manual locking mechanism and the button controlled alarm mechanism.
\end{abstract}

\section{Introduction}

Donation boxes are often being seen in public places that receive a lot of visitor such as mosque or mall as a means of generating additional revenue in small increments. In churches, it is common to find a Mite box or Alms Box, and in Shinto shrines a Saisen-bako.

The term of mite box or generally known as donation box (also alms box or poor box) refers to a box that is used to collect coins and money bills for charitable purposes. The mite boxes are collected by the church, mosque or temple, and the donations are given to the poor.

Donation box is firstly used to collect money for the worshipping place funding rather than giving some alms [1]. It is also helps the people to do charity more conveniently as they only need to insert the money or clothes inside the box. A man has been arrested by the public member as he was attempting to steal from a donation box from the local Hindu temple [2]. Mohd [3] also wrote news about the caught of a band of thieves that are targeting the donation box placed inside the mosque. These bands of thieves are believed to be involved also in the other several cases of the stolen donation box around Malaysia.

Based from these two statements, donation box which is being left unattended has become the target of thieves. This happen because the current design of the donation is lack of safety feature, making it easier for the thieves to stole the money inside the donation box. The safety feature of the current donation boxes is solely depending on the locking mechanism which normally includes a lock only. Therefore, it is crucial to design an anti-thief donation box which include extra safety features in order to reduce the risk where the donation are being stolen.

\section{Anti-Thief Donation Box Design Material and Method}

The aim of this project is to design an anti-thief donation box that can overcome or reduce loss of donation to the public. The objective is to design a locking mechanism that will act as the safety feature of the donation box and designing a donation box that made up from material that can withstand high force and is very durable.

\subsection{Proposed Design}

Four concept of the purpose design of the Anti-thief donation box are shown in Figure.1. The characteristic of safety measurement, material strength and durability, product durability, and the design are considered during the design stage for this anti-thief donation box[4]. The detailed explanations for each design are also included.

*Corresponding author: febrian@utem.edu.my 


\section{Concept 1}

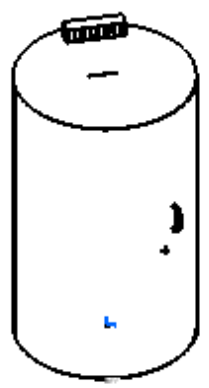

\begin{tabular}{|c|c|l|}
\hline No & Characteristic & \multicolumn{1}{|c|}{ Type } \\
\hline 1 & Shape & Cylinder \\
\hline 2 & Height & $100 \mathrm{~cm}$ \\
\hline 3 & Material & Iron \\
\hline 4 & Alarm System & Siren \\
\hline 5 & Power System & Alternating current \\
\hline 6 & Locking System & $\begin{array}{l}\text { Sensor Locking } \\
\text { System }\end{array}$ \\
\hline 7 & Lock Type & $\begin{array}{l}\text { Mechanical Cupboard } \\
\text { Lock }\end{array}$ \\
\hline 8 & Bill and coin slot & Normal Slot \\
\hline 9 & $\begin{array}{c}\text { Compartment of } \\
\text { Donation Box }\end{array}$ & Single \\
\hline 10 & Door Handle & Rectangular Shape \\
\hline
\end{tabular}

Concept 2

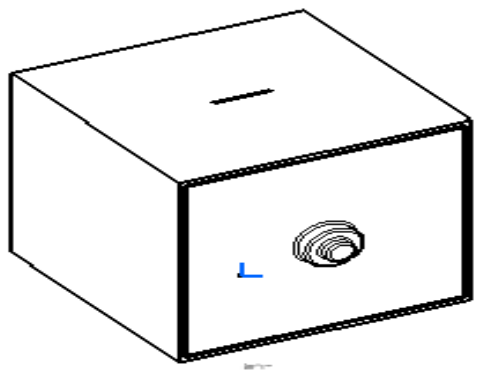

\begin{tabular}{|l|l|l|}
\hline No & \multicolumn{1}{|c|}{ Characteristic } & \multicolumn{1}{|c|}{ Type } \\
\hline 1 & Shape & Rectangular \\
\hline 2 & Height & $50 \mathrm{~cm}$ \\
\hline 3 & Material & Cement \\
\hline 4 & Alarm System & Magnetic \\
\hline 5 & Power System & Direct current \\
\hline 6 & Locking System & $\begin{array}{l}\text { Simple Dua- } \\
\text { Locking System }\end{array}$ \\
\hline 7 & Lock Type & $\begin{array}{l}\text { Combination lock } \\
\text { and mechanical } \\
\text { cupboard lock }\end{array}$ \\
\hline 8 & Bill and coin slot & Rectractable Slot \\
\hline 9 & $\begin{array}{l}\text { Compartment of Donation } \\
\text { Box }\end{array}$ & Single \\
\hline 10 & Door Handle & Semicircle Shape \\
\hline
\end{tabular}

\section{Concept 3}

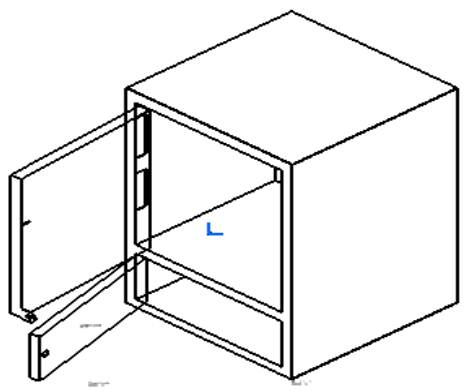

\begin{tabular}{|l|l|l|}
\hline No & \multicolumn{1}{|c|}{ Characteristic } & \multicolumn{1}{c|}{ Type } \\
\hline 1 & Shape & Rectangular \\
\hline 2 & Height & 100 cm \\
\hline 3 & Material & Two steel plates \\
\hline 4 & Alarm System & Speaker \\
\hline 5 & Power System & $\begin{array}{l}\text { Direct current } \\
\text { Syal- Locking } \\
\text { mechanical } \\
\text { mechanism }\end{array}$ \\
\hline 6 & Locking System & $\begin{array}{l}\text { Mechanical } \\
\text { cupboard lock }\end{array}$ \\
\hline 7 & Lock Type & Normal slot \\
\hline 8 & Bill and coin slot & Double \\
\hline 9 & $\begin{array}{l}\text { Compartment of Donation } \\
\text { Box }\end{array}$ & L-shaped \\
\hline 10 & Door Handle & \\
\hline
\end{tabular}

Concept 4

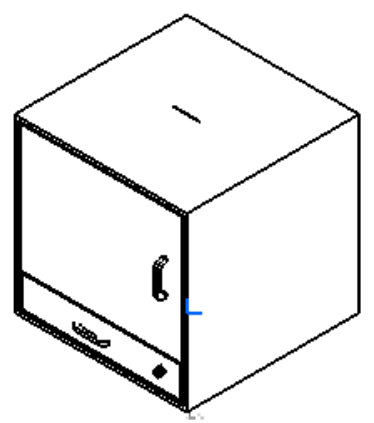

\begin{tabular}{|l|l|l|}
\hline No & \multicolumn{1}{|c|}{ Characteristic } & \multicolumn{1}{c|}{ Type } \\
\hline 1 & Shape & Cube \\
\hline 2 & Height & $50 \mathrm{~cm}$ \\
\hline 3 & Material & Steel plates \\
\hline 4 & Alarm System & Speaker \\
\hline 5 & Power System & Direct current \\
\hline 6 & Locking System & $\begin{array}{l}\text { Simple Dual- } \\
\text { locking System }\end{array}$ \\
\hline 7 & Lock Type & $\begin{array}{l}\text { Mechanical } \\
\text { cupboard lock }\end{array}$ \\
\hline 8 & Bill and coin slot & Normal slot \\
\hline 9 & $\begin{array}{l}\text { Compartment of } \\
\text { Donation Box }\end{array}$ & Double \\
\hline 10 & Door Handle & Semicircle shape \\
\hline
\end{tabular}

Fig 1. Concept 1,2,3,4 for the Anti-Thief Donation Box 


\subsection{Conceptual Design of Anti-Thief Donation Box}

Concept design 3 is selected as the best design to be fabricated because the design fulfils all the criteria listed by the customers. This design has the best locking mechanism and alarm system that can improve the security aspect of this box. The material for this box that is mild steel has the perfect strength and durability to make the box capable to withstand big forces.

A block diagram of product component decomposition is drawn as shown in Table 1. The donation box is designed to prevent thief therefore it is created to have dual locking system, two compartment that is upper and lower, an alarm system and finally the outer part and inner part. This ensures the security, durability and strength of the product. Every single part has its own function in order for the device to function well.

Table 1: Decomposition of the Anti-thief donation box

\begin{tabular}{|l|l|}
\hline \multicolumn{2}{|c|}{ Anti-Thief Donation Box } \\
\hline $\begin{array}{l}\text { Strength and Durability } \\
\text { Aspect }\end{array}$ & \multicolumn{1}{|c|}{ Safety Measure } \\
\hline - Consist of outer and inner & • Dual Locking System \\
part & • Digital lock \\
- Have upper and lower & - Combination Lock \\
part of compartment & • Alarm System \\
- Fully consist of mild steel & \\
\hline
\end{tabular}

The Anti-Thief donation box is functioning by activating the alarm in the upper compartment. The user can control the alarm by pushing the button that is installed in the lower compartment. To open the upper compartment, the user needs to open the lower compartment door first. Then, after unlocking the mechanical lock, the user needs to insert the saved pass code into the digital lock.

Table 2: The Functional Decomposition Of The Anti-Thief Donation Box.

\begin{tabular}{|c|c|c|c|}
\hline \multicolumn{4}{|c|}{ Transfer the patient from wheelchair to bed } \\
\hline $\begin{array}{l}\text { Lower } \\
\text { Compartment }\end{array}$ & $\begin{array}{l}\text { Mechanical } \\
\text { Lock }\end{array}$ & $\begin{array}{l}\text { Digital } \\
\text { Lock }\end{array}$ & $\begin{array}{l}\text { Alarm } \\
\text { System }\end{array}$ \\
\hline $\begin{array}{l}\text { Equipped } \\
\text { with a } \\
\text { combination } \\
\text { lock } \\
\text { The } \\
\text { mechanical } \\
\text { lock is } \\
\text { installed }\end{array}$ & $\begin{array}{l}\text { Control the } \\
\text { upper } \\
\text { compartment. } \\
\text { Steps } \\
\text { requirement } \\
\text { Increase the } \\
\text { security }\end{array}$ & $\begin{array}{l}\text { pass code } \\
\text { is inserted } \\
\text { mechanical } \\
\text { lock to } \\
\text { increase the } \\
\text { safety }\end{array}$ & $\begin{array}{l}\text { Safety } \\
\text { measure. } \\
\text { Gives } \\
\text { warning } \\
\text { alert } \\
\text { Button } \\
\text { Controlled }\end{array}$ \\
\hline
\end{tabular}

\section{Results}

Pugh concept section method is used to evaluate the concept alternatives. Criteria choose are high efficiency, high reliability, low maintenance, low cost and light weight. Concept 1 was selected as Datum which is a benchmark comparison of a product. 
Table 3: Pugh Method Selection

\begin{tabular}{|c|c|c|c|c|c|}
\hline \multirow{2}{*}{ Criterion } & \multirow{2}{*}{$\begin{array}{c}\text { Importance } \\
\text { Weightage } \\
(\%)\end{array}$} & \multicolumn{4}{|c|}{ Concept } \\
\hline & & Concept & $\begin{array}{c}\text { Concept } \\
2\end{array}$ & $\begin{array}{c}\text { Concept } \\
3\end{array}$ & $\begin{array}{c}\text { Concept } \\
4\end{array}$ \\
\hline High strength of the product & 20 & \multirow[b]{2}{*}{ D } & + & + & + \\
\hline Long life span & 10 & & + & + & + \\
\hline High security of the product & 25 & \multirow[b]{2}{*}{ 政 } & - & + & - \\
\hline High endurance of heat & 10 & & + & + & $\mathrm{S}$ \\
\hline $\begin{array}{l}\text { Manufacturing cost } \\
(\mathrm{RM} / \cos \mathrm{t})\end{array}$ & 10 & $\mathbf{T}$ & $\mathrm{S}$ & - & $\mathrm{S}$ \\
\hline Easy access for maintenance & 5 & \multirow{2}{*}{$\mathbf{U}$} & - & - & $\mathrm{S}$ \\
\hline Complicated locking system & 10 & & $\mathrm{~S}$ & + & - \\
\hline High durability & 10 & & + & + & + \\
\hline \multicolumn{2}{|l|}{ Total + } & & 50 & 85 & 40 \\
\hline \multicolumn{2}{|l|}{ Total - } & & 30 & 15 & 35 \\
\hline \multicolumn{2}{|l|}{ Total S } & & 20 & 0 & 25 \\
\hline \multicolumn{2}{|c|}{ Weighted total $=($ Total +$)-($ Total -$)$} & & 20 & 70 & 5 \\
\hline
\end{tabular}

The concept 1 is set as datum column. +, -, = sign is used against datum to evaluate and compared the other concepts. Finally, select the best alternative configuration as the final configuration where were concept 3 .

\subsection{Fabrication of Product}

For this product, the fabrication process involved is cutting and welding. First of all, the mild steel plate is being measured and cut into desired size. Then the parts will be combining by welding the steel plate together to form a box [5-6]. The electronic component of the product is being installed using hot glue gun and soldering. Figure 2 below shows the final product after the fabrication process.

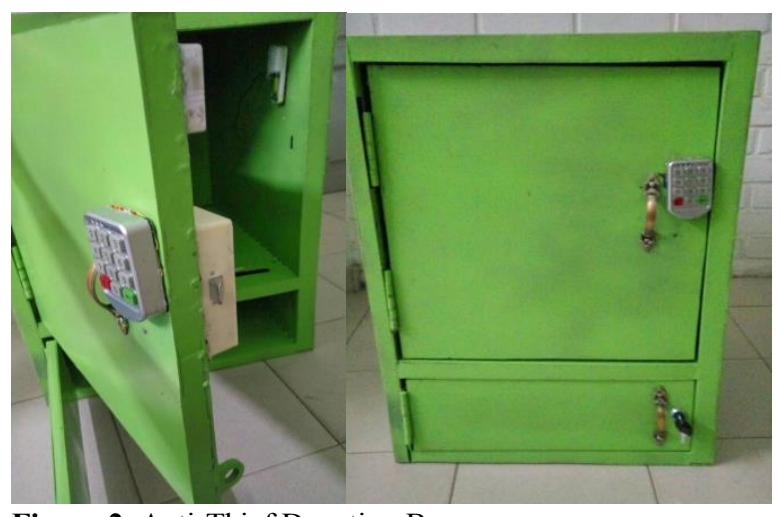

Figure 2. Anti-Thief Donation Box

\subsection{Mechanical Analysis Aspect}

From the analysis aspect, the box is designed to be able to withstand strong forces. That is why, for this product, mild steel is selected as it base material. Mild steel has the perfect ultimate strength of $400 \mathrm{MPa}$. Based on the Finite Element Analysis and hardness testing, mild steel has the most suitable strength and durability.

The dual-locking mechanism is designed to be fully mechanically functioning. This because, we want to create locking system that is easy to operate and 
maintain. The dual locking mechanism does no required outer power source as it is design to function only by retracting it forward and backward.

\subsection{Health, Safety, Environment and Sustainability}

The Anti-thief donation box was designed to have a perfect dimension where it suitable for people to insert money without having to bend themselves down. This design was different from the current design of donation box which comes in small sizes that need people to bend when they want to insert the money into the donation box money slot. Other than that, the upper compartment that keeps the money storage is designed to ease the owner to pull the box out and installed it back into position. The material use for the product is user friendly and did not cause any harm to the human health.

This donation is designed to fulfil the anti-thief theme. However, the safety aspect is considerate which is harmless to the people surrounding. Therefore, the donation box did not have any sharp edges. The donation box is also designed to have two compartments which have separate function. These designs make sure the product is compatible and safe to the user and people surrounding. The processes of creating the Anti-Thief donation box are also being done under the supervision of the specialist.

Sustainable design or also known as environmental design an environmentally sustainable design, is the philosophy of designing physical objects, the built environment, and services to comply with the principles of social, economic, and ecological sustainability. Eliminating negative environmental impact completely through skilful and sensitive design has been the main intention of sustainability design. Sustainability design manifestations require renewable resources, minimally impact the environment and at the same time connecting the user with the natural environment [7]. Other than the "elimination of negative environmental impact", sustainable design must also create projects that can provide meaningful innovations that can shift behaviour. A dynamic balance between economy and society, intended to generate long-term relationships between user and object or service and finally to respect and considered the Mother Nature and social differences.

Therefore, by following the twelve-sustainability design principle [8-9], the product was followed as an environment-friendly product. The material used to make the thief-nightmare donation box is did not contain any harmful substance and chemical. The mild steel that is being used for the product can be recycled when the product is not functioning anymore.

Not only are the materials, the process of creating the product also following the principle. The processes that involved when creating the product are being done in specifically place. For example, the process of combining the box required the mild steel plate to weld together. Welding process itself taking place in the welding laboratories which are specifically designed for the process. During the process, we did not do anything that can cause harm to the environment.

\section{Conclusion}

Anti-Thief Donation Box has been studied, designed and fabricated at Faculty of Mechanical Engineering (FKM), Universiti Teknikal Malaysia Melaka (UTeM). A few methods such as Product design specification (PDS), concept generation, Pugh selection method for criteria decision making process during design has been performed in order to decide and select the best design from safety measure, material strength and durability, and product design perspective. The donation box concept design 3 has been selected due to matching the best criteria set in Pugh selection method.

The authors would like to acknowledge Centre for Research Innovation Management (CRIM), UTeM especially faculty Centre for Advanced Research on Energy, (CARe) and Innovation and Sustainability in Machine Technologies (iSMAT) as a research group for providing facilities in carrying out this study.

\section{References}

[1] V.J.B. Carrera (1828). Encyclopaedia Dictionary History, Imp. Roca. Pp.457- Retrieve 6 April 2013.

[2] B. Mohd (2017). Three friends jailed for stealing from mosque donation box. Retrieved May 21, 2017, from http://www.malaysiakini.com/news/370265

[3] X. Liu, Z. Kuang, L. Yin, L. Hu,(2017) Structural reliability analysis based on probability and probability bos hybrid model. Jounal of Structural safety, Volume 68, pp 7384.

[4] Idral. F, (2010), Conceptual Design of a Single Seater Formula Racing Car Final Year Project Report, (Universiti Teknikal Malaysia Melaka (UTeM), Melaka, Malaysia.

[5] Gerard, Barbara (2015)."What is ASTM International? Retrieved 1 February 201 from http://info.craftechind.com/blog/what-is-astminternational

[6] Steel Construction Manual, 8th Edition, second revised edition, American Institute of Steel Construction, 1986, Ch. 1 pp. 1-5.

[7] J.F. McLennan (2004). The Philosophy of Sustainable Design. Ecotone Publishing. Seattle, USA. 
[8] Anastas, P., \& Zimmerman, J. (2007). Design Through the 12 Principles of Green Engineering. IEEE Engineering Management Review,35(3), 16-16. doi:10.1109/emr.2007.4296421

[9] F. Ceschin, (2016), Evolution of Design for Sustainability; From Product Design to Design for System Innovation and Transitions, Design Studies, Volume 47, pp 118-163. 